\title{
In Situ Aldehyde Enolate Formation by Rhodium-Catalyzed Isomerization
}

Category

Metal-Catalyzed Asymmetric Synthesis and Stereoselective Reactions

\section{Key words}

rhodium

aldol reaction

aldehydes

allylic alcohols

allyloxyboranes

Isomerization-cross-aldol reaction with triallylboranes:

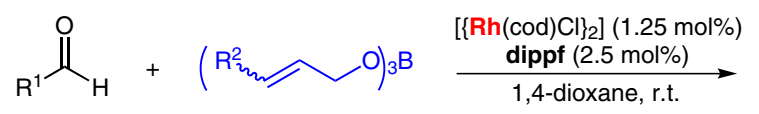

Selected examples:<smiles>[R]CC(C=O)C([R])O</smiles>

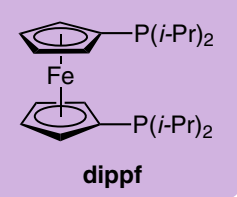<smiles>CC(C=O)C(O)c1ccccc1Br</smiles>

$99 \%$ yield $\mathrm{dr}=94: 6$<smiles>CCC(C=O)C(O)c1ccccc1</smiles>

$93 \%$ yield<smiles>CCCCCC(O)C(C)C=O</smiles>
$73 \%$ yield
$d r=85: 15$<smiles>CC(C=O)C(O)[C@H]1COC(C)(C)O1</smiles>

Isomerization-cross aldol reaction with allylic alcohols:<smiles>CCC(O)C(C=O)CC</smiles>

$$
\begin{aligned}
& 71 \% \text { yield } \\
& \mathrm{dr}=75: 25
\end{aligned}
$$

$75 \%$ yield $\mathrm{dr}=73: 22: 4: 1$<smiles>[R2]C=CC(O)[R19](C)=O</smiles>

Selected examples:<smiles>CC(C=O)C(O)c1ccccc1</smiles>

$73 \%$ yield $\mathrm{dr}=86: 14$<smiles>CC(=O)C(C)C(O)c1ccccc1</smiles>

$90 \%$ yield $\mathrm{dr}=86: 14$<smiles>CCCCCC(O)C(C)C(C)=O</smiles>

$96 \%$ yield $\mathrm{dr}=83: 17$<smiles>CCC(C(C)=O)C(O)c1ccccc1</smiles>

$87 \%$ yield

Isomerization-cross aldol with homoallyloxyborane and homoallylic alcohol:

$$
\text { (2) }
$$

Significance: Aldol reactions in which the aldol donor is derived from an aldehyde, are particularly challenging. This report describes a strategy in which aldehyde enolates are generated in situ by rhodium-catalyzed isomerization of triallylboroxanes. High syn-selectivity is obtained for a variety of aldehyde-donor and-acceptor partners.
Comment: Remarkably, the use of triallyloxyboranes is not required; simple primary and secondary allylic alcohols also undergo the isomerizationcross-aldol sequence with similar levels of reactivity and selectivity, presumably through a rhodiumenolate or -enol mechanism. 